\title{
NEW TENDENCIES IN PUBLIC PROCUREMENT - A WAY TOWARDS LEVELLING PLAYING FIELD OR A GLIMPSE OF PROTECTIONISM?
}

\author{
Tomislav Sadrić, mag. iur. \\ Batarelo Dvojković Vuchetich law firm LLP \\ Amruševa 19, 10000 Zagreb, Croatia \\ tomislav.sadric@bdvlegal.com
}

\begin{abstract}
The purpose of this paper is to present the White Paper on levelling the playing field as regards foreign subsidies, from the public procurement perspective. This is the first time that the problem of foreign subsidies within public procurement is approached by European Commission and it is useful to analyse Commission's findings on that regard. Due to the problems caused by COVID-19 pandemic and the forthcoming Next Generation EU initiative, the Commission is determined to develop and implement suitable legal instruments for dealing with distortions in the Internal Market, caused by foreign subsidies. Legal analysis within the paper is focused on the proposed Module 3 under the White Paper, trying to detect possible practical repercussions of implementing measures as are proposed in the White Paper. In addition, the paper seeks to identify primary function of the measures proposed and tries to examine if that function could result in protectionist effects.
\end{abstract}

Keywords: foreign subsidies, level playing field, open competition principle, protectionism, public procurement, State aid

\section{INTRODUCTION}

The COVID-19 pandemic has caused unprecedented worldwide challenges, primarily in the area of public health, followed with sharp repercussions within national economies, politics and social relations. EU has not been spared of such challenges, instead due to its unique supranational nature it must deal with some additional issues caused by the pandemic. To help its heavily affected economies, EU has prepared a Next Generation EU initiative - the temporary instrument designed to boost the recovery, based on EUR 750 billion of public funds to be 
injected into European economies. ${ }^{1}$ Preparation of Next Generation EU initiative coincided with designing the new Multiannual Financial Framework 2021-2027., amounting to EUR 1.074 trillion. ${ }^{2}$ It may be safely anticipated that such large amounts of EU funds will boost public spending and public investments, which will certainly bring about a significant increase of complex and high value public procurement procedures.

Stating that public procurement and competition law have a lot in common would be the least original thing to assert. This is a matter already argued in detail within legal doctrine. ${ }^{3}$ Not only that, a clear connection between public procurement and competition law is evident from the fact that the principle of competition is explicitly embedded in the EU procurement $\mathrm{law}^{4}$, as a one of the fundamental or general principles of the EU public procurement regime. ${ }^{5}$ While the issue of scope and reach of competition principle within public procurement is open for discussion, there is no question that any idea of implementing restrictive measures or approaches in connection to public procurement has its reflections in the field of EU competition policies, and as such it should be also assessed from a competition policy standpoint.

The pandemic crisis has strengthened initiatives within the EU, seeking for stronger protection of EU based economic operators against unfair competitors from non-EU countries, which are allegedly subsidized by their governments in a way that is contrary to the EU State aid rules. Those initiatives rest on a claim that due to such subsidies, foreign competitors obtain advantages over EU economic operators when participating in EU public procurement procedures. Although those initiatives are not quite new, due to economically and politically delicate situation, EU decided to took a firm step this time. Such reaction is unsurprising, given that the European economies are heavily affected by the pandemic, a recovery is mainly planned through public investments, which imply a lot of public procurements, and a large part of allegations on unfair subsidies are addressed to Chinese companies winning procurement procedures in EU Member States in recent years, all of that happening in a delicate moment in relations of EU and China. There is no

1 EU's next long-term budget\& Next Generation EU: key facts and figures, 2020, [https://ec.europa.eu/ info/sites/default/files/about_the_european_commission/eu_budget/mff_factsheet_agreement_en_ web_20.11.pdf], Accessed 20 April 2021.

2 ibid.

3 A fascinating study on this matter is provided in: Sanchez-Graells, A., Public Procurement and the EU Competition Rules, Hart Publishing, Oxford, 2015.

4 Directive 2014/24/EU of the European Parliament and of the Council of 26 February 2014 on public procurement and repealing Directive 2004/18/EC (Directive 2014/24/EU), OJ L 94, art. 18 (1).

5 Sanchez-Graells, op. cit., note 3, p.195. 
doubt that a significant amount of pressure urging EU institutions to act against foreign subsidies comes from European based economic operators, their sectoral associations and trade groups. Their motive is for sure of economic origin, arising out of the fact that in recent years companies outside EU were awarded with several high-valued public contracts, especially in the sector of public infrastructure. In Croatia for instance, a key infrastructure project, construction of Pelješac bridge of total value over EUR 520 million, was awarded to China Road and Bridge Corporation, a Chinese state-owned company. But, at the same time motives connected with geopolitics and national security issues should not be overlooked or underestimated, especially when it comes to the procurement of sensitive or critical infrastructure. In that regard, it was noted recently by the media that some European countries are starting to block Chinese involvement in their economies, by cancelling public tenders that Chinese state-owned companies were set to win, drawing closer to positions advocated by the USA. ${ }^{6}$ According to the same media sources, such shift is motivated by a mix of national security concerns and disappointment with the previous performance of Chinese contractors. ${ }^{7}$ As always when it comes to national security questions, it is hard to assess to which extent such assumptions are founded. Either way, it does not escape notice that the Rijeka Port, acting as the contracting authority in the procedure of granting the concession for development and economic use of the Zagreb Deep Sea container terminal in Rijeka, at the end of 2020 annulled the granting procedure, after a consortium of Chinese companies submitted the best offer and was likely to win. The reasoning for the annulment offered in the decision rendered by the contracting authority very briefly invoked the pandemic as the main reason for the annulment, lacking any elaboration on the causal link between the pandemic and the annulment of the concession procedure. ${ }^{8}$

In order to address the issue of foreign subsidies, during 2020 the Commission has adopted a White Paper on levelling the playing field as regards foreign subsidies $^{9}$, aim of which is to deal with the distortive effects caused by foreign subsidies in the Single Market. Three modules have been developed in the White Paper, representing instruments of the future regulatory framework designed to address distortions caused by foreign subsidies in the Single Market.

6 Michaels, D., Pop, V., China faces European obstacles as some countries heed U.S. pressure, The Wall Street Journal online edition, [https://www.wsj.com/articles/china-faces-european-obstacles-as-somecountries-heed-u-s-pressure-11614088843] Accessed 20 April 2021.

$7 \quad$ Ibid.

8 Decision of Port Rijeka Authority No UP/I-342-01/20-01/26 of 30 December 2020.

9 European Commission, White Paper on levelling the playing field as regards foreign subsidies of 17 June 2020, COM(2020) 253 final (White Paper). 
The aim of this paper is to analyze current state of affairs in the field of the EU public procurement law and policy, in the context of the novelties announced by the White Paper. It should be noted that the White Paper is designed to tackle foreign subsidies issues not only within public procurement, but within a much broader scope of economic activities. However, this paper should focus only on the procurement matters, with an emphasis on a Module 3 designed in the White Paper.

\section{FOREIGN SUBSIDIES AND EU PUBLIC PROCUREMENT - THE CURRENT STATE OF PLAY}

\subsection{General Remarks Given by the Commission in the White Paper}

Among introductory remarks to the White Paper, the Commission presented a detailed overview of the current state of play as regards foreign subsidies in the Internal Market. The overview consists of general remarks on the openness of EU's procurement market to foreign economic operators, followed with a brief analysis of risks that could arise in connection to such openness. The Commission emphasized the role and importance of EU State aid rules in preserving level playing field in the Internal Market. Further, several objectives which non-EU countries pursue by subsidizing its economic operators engaging in the Internal Market are identified as well as certain regulatory shortcomings and gaps in the EU legal framework regarding foreign subsidies which should be overarched by the proposed measures and instruments.

In the White Paper the Commission emphasizes the importance of general openness of the EU economy to foreign investment, and substantiates this remark by recent economic data. ${ }^{10}$ The same applies to the EU procurement markets, which are, from the Commission's point of view, largely open to third country bidders, while EU-wide publication of tenders ensures transparency and creates market opportunities for EU and non-EU companies alike. ${ }^{11}$ At the same time, the Commission warns that such openness to foreign undertakings has come with increased risks, such as foreign subsidization, which needs to be controlled to avoid undermining competitiveness and the level playing field in the EU market. ${ }^{12}$ With regard to public procurement, the Commission asserts that companies subsidized from the outside of EU may be able to make more advantageous of-

White Paper p. 6.

White Paper p. 7.

White Paper p. 6. 
fers, to the detriment of non-subsidized EU based undertakings. ${ }^{13}$ In the same context, the Commission points out that the risk of intra-EU State subsidies are largely solved by the EU State aid rules, which help to preserve a level playing field in the Internal Market among undertakings. ${ }^{14}$ However, Commission notes that currently there are no equivalent EU rules for subsidies that non-EU authorities grant to undertakings operating in the Internal Market, and that due to a lack of transparency there is only a limited information on the actual amount of foreign subsidies being granted to such undertakings. ${ }^{15}$ The Commission is taking into account that, just as in the case of State aid granted by EU Member States, foreign subsidies can also distort competition in the Internal Market, result in an uneven playing field or lead to subsidy races between public authorities. ${ }^{16}$ At the same time, the Commission rightly observes that many public buyers, mindful of their budgets, have an incentive to award contracts to bidders offering low prices regardless of whether those prices are facilitated by foreign subsidies. ${ }^{17}$

In an effort to identify and define possible consequences of foreign subsidies, the Commission brings the economic repercussions to the fore, by pointing out that foreign subsidies may lead to an inefficient overall allocation of resources and, more particularly, a loss of competitiveness and innovation potential of companies that do not receive such subsidies. ${ }^{18}$ However, the Commission does not stop itself within economic terms. On the contrary, the Commission emphasizes that there could be several additional objectives which non-EU authorities pursue by granting foreign subsidies, not necessarily entirely of economic nature. ${ }^{19}$ By way of example, the Commission asserts that in some cases, granting of foreign subsidies can also be driven by a strategic objective to establish a strong presence in the EU or to secure access and later to transfer technologies to other production sites, possibly outside of the EU. ${ }^{20}$ Furthermore, according to the Commission's standpoint, foreign subsidies, not driven by normal commercial considerations, may be driven by strategic goals, in order to get a foothold in strategically important markets or regions, or to get privileged access to critical and major infrastructure within EU. ${ }^{21}$ Although reasons of national and EU security are not invoked largely

\footnotetext{
White Paper p. 7.

White Paper p. 6.

White Paper p. 6.

White Paper p. 7.

White Paper p. 8.

White Paper p. 7.

White Paper p. 8 .

White Paper p. 8

White Paper p. 8.
} 
in the White Paper, it is hard not to notice that mention of critical infrastructure in this context is a reference exactly to that.

According to the White Paper, foreign subsidies may take different forms. For example, subsidies can be awarded as direct grants, or could take a form of cheaper financing provided to an undertaking in the EU. Foreign states may also give a subsidy to a parent company located outside the EU, in which case such subsidies may also take a form of corporate tax regimes providing selective incentives, which then in turn finances the subsidiary located in the EU through intragroup transactions. Finally, foreign subsidies can also be channeled to the undertakings operating in the Internal Market through investment funds or intermediaries supported by a foreign government. ${ }^{22}$

\subsection{Legal Framework Analysis and the Concept of Abnormally Low Tender as a Tool to Tackle Foreign Subsidies}

The Commission invested significant efforts into detailed analysis of the existing EU legal framework, in order to detect regulatory gaps that are used for channeling the foreign subsidies into the Internal Market. As regards the EU public procurement legal framework, the Commission finds that it does not specifically address distortions to the EU procurement markets caused by foreign subsidies. As single market instruments, the EU Public Procurement Directives do not set out any specific rules regarding the participation of economic operators benefitting from foreign subsidies. ${ }^{23}$ For instance, contracting authorities are not legally required to investigate the existence of foreign subsidies when evaluating offers and no specific legal consequences are attached to the existence of foreign subsidies causing a distortion..$^{24}$

The White Paper recognizes that contracting authorities do not possess adequate tools to tackle foreign subsidies. For now, the only instrument available to deal with subsidies in general is envisaged in art. 69 of Directive 2014/24/EU. ${ }^{25}$ In brief, this provision says that contracting authorities shall require economic operators to explain the price or costs proposed in the tender where tenders appear to be abnormally low in relation to the works, supplies or services. The contracting authority shall assess the explanatory information provided by consulting the tenderer. It may only reject the tender where the evidence supplied does not sat-

\footnotetext{
$22 \quad$ White Paper p. 8.

23 White Paper p. 10.

24 White Paper p. 10.

25 White Paper p. 11.
} 
isfactorily account for the low level of price or costs proposed and are obliged to reject the tender if they establish that the tender is abnormally low because it does not comply with mandatory laws in the fields of social, labour or environmental law. In addition, the art. 69 envisages a separate basis for rejecting the tender in case a contracting authority establishes that a tender is abnormally low because the tenderer has obtained State aid incompatible with the Internal Market. In that case the tender may be rejected on that ground alone, but the tenderer should be given the chance to prove that the aid in question was compatible with the Internal Market within the meaning of art. 107 TFEU.

The concept of abnormally low tender lies on the premise that a tenderer may submit an unusually low bid due to legitimate or illegitimate factors. ${ }^{26} \mathrm{~A}$ competitive advantage of a tenderer, based on its greater efficiency or cheaper inputs could be used as an example of legitimate factors for low tendering. On the other side, illegitimate factors for a low tender could consist of underpayment of staff or subcontractors, or failure of a tenderer to abide by relevant legislation. ${ }^{27} \mathrm{~A}$ rationale behind the provision governing abnormally low tenders is sometimes found in the argument that abnormally low tender might be unviable, due to technically, economically or legally unsound assumptions or practices, ${ }^{28}$ causing increased risk of non-performance and undermining the objectives for which contracting authority initiated the procurement procedure. Some authors use this line of argumentation to conclude that the purpose of regulating the abnormally low tenders is primarily to protect contracting authorities, but that some elements of protection for the economic operators are also present, due to the fact that the art. 69 of the Directive 2014/24/EU prevents the contracting authority in rejecting a tender without giving the tenderer a chance to explain why the tender is abnormally low. ${ }^{29} \mathrm{In}$ contrast, other scholars emphasize the art. 69 should be understood as a mechanism to prevent discretionary or arbitrary decisions of contracting authorities, by imposing procedural guarantees to be complied with by contracting authorities prior to rejecting apparently abnormally low tenders. ${ }^{30}$ Either way, it could be concluded that the primary purpose of the art. 69 is not to provide protection to other economic operators participating in the procurement procedure, against the tenderer who submitted allegedly abnormally low tender due to some illegitimate factor.

\footnotetext{
26 Semple, A., A practical guide to public procurement, Oxford University Press, Oxford, 2015, p. 163.

27 Ibid.

28 Steinicke, M., Vesterdorf P., L., EU public procurement law, Nomos Verlagsgesellschaft, Baden-Baden 2018., p. 771.

$29 \quad$ Ibid. p. 772.

30 Sanchez-Graells, op. cit., note 3, p. 401-402.
} 
As a general remark, it should be added that a significant amount of the difficulties encountered at the application of the art. 69 arises out of the fact that the Directive 2014/24/EU does not define what constitutes an abnormally low tender. At the same time, there are no other rules outlining a method which can be applied in order to determine if a tender is abnormally low, ${ }^{31}$ leaving it to national measures, or in their absence to the contracting authority, to determine how such tenders will be identified, ${ }^{32}$ which leads to the conclusion that divergences in national approaches to the identification of abnormally low tenders could not be overcome. ${ }^{33}$

At first glance, it seems that art. 69(4) could be suitable to tackle tenders tainted by foreign subsidies. Indeed, under art. 69(4) in order to reject a tender, it is sufficient to establish that the tender is abnormally low because the tenderer has obtained State aid incompatible with the Internal Market. However, a major obstacle to invocation of art. 69(4) in cases of foreign subsidies lies in the notion of State aid, as used in this provision. It is obvious that the notion of State aid used in art. 69(4) is identical as the one given by art. $107 \mathrm{TFEU}$, limiting its scope to aid granted by a Member State or through Member State resources, hence not including subsidies granted by third states. In the same vein, the White Paper clearly states that the art. 69 contains no corresponding provision for foreign subsidies that enable bidders to submit low offers. ${ }^{34}$

Considering that art. 69(4) could not be invoked against foreign subsidies, another option is to use a general rule given by art. 69(3), which entitles contracting authorities to reject tenders if evidence supplied by the tenderer does not show viability of the tender, thus preventing the risk of non-performance. This approach was advised in an earlier communication from the Commission, giving guidance on the participation of third-country bidders and goods in the EU procurement market. ${ }^{35}$ The Commission then recommended to public buyers to pay special attention to bids offering goods or services from third countries whose prices and costs may be distorted by state-backed financing. According to that guidance, the existence of financial support from a foreign state could form part of the global assessment of the viability of the offer. ${ }^{36}$ The same approach is once again repeated in the White Paper, asserting that public buyers may consider the reliance on foreign subsidies when assessing the overall financial viability of an offer. For this

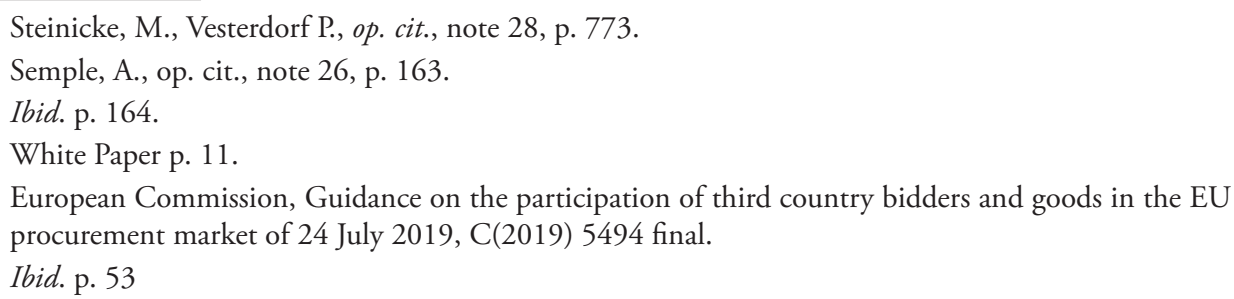


assessment, art. 69 provides the contracting authorities with the possibility to reject offers they consider to be abnormally low in situations where the explanations and evidence supplied by the bidder do not sufficiently account for the low price offered. ${ }^{37}$ But, even if the public buyers ultimately decide to reject an offer as abnormally low, the White Paper confirms that such a rejection needs to be justified by demonstrating that the foreign subsidies impede the viability of the offer and the bidder's capacity to execute the contract. ${ }^{38}$ To conclude on this approach advised by the Commission, it should be stated that it is not quite clear in which way foreign subsidy may impede the viability of the offer. Namely, if a tenderer has been granted with a state-backed financing in support to its tender, then such subsidy in most cases would not impede the viability of its offer. On the contrary, such subsidy may be a key evidence of viability of the offer, because it proves that the contract can be performed as agreed, due to the subsidy granted by the third country. Having that in mind, it is not to be expected that art. 69 could be used efficiently to tackle foreign subsidies. At the end of the day, it is already stated above that the purpose of art. 69 is to provide protection to contracting authorities (against risk of non-performance) and to tenderers (against arbitrariness of contracting authorities) and not to remedy the distortions caused by foreign subsidies in the Single Market. The Commission reaches the same conclusion, stating that the existing rules in the field of EU public procurement are not sufficient to address and remedy the distortions caused by foreign subsidies. Hence, where foreign subsidies facilitate and distort the bidding in an EU public procurement procedure, there appears to be a regulatory gap. ${ }^{39}$

\section{MEASURES PROPOSED TO TACKLE FOREIGN SUBSIDIES - A BRIEF ANALYSIS}

\subsection{Module 3 - Procedure and Redressive Measures}

The White Paper brings a definition of foreign subsidy, stating that the suggested notion of "foreign subsidies" builds on the subsidy definition set out in the EU Anti-subsidy Regulation ${ }^{40}$ and in the EU Regulation on safeguarding competition in the air transport sector ${ }^{41}$ as well as on the subsidy definition set out in the

\footnotetext{
37 White Paper p. 11.

38 White Paper p. 11.

39 White Paper p. 12.

40 Regulation 2016/1037 of the European Parliament and of the Council of 8 June 2016 on protection against subsidised imports from countries not members of the European Union, OJ L 176.

41 Regulation 2019/712 of the European Parliament and of the Council of 17 April 2019 on safeguarding competition in air transport, and repealing Regulation (EC) No 868/2004, OJ L 123.
} 
relevant WTO rules. ${ }^{42}$ According to the White Paper a "foreign subsidy" refers to a financial contribution by a government or any public body of a non-EU State, which confers a benefit to a recipient and which is limited, in law or in fact, to an individual undertaking or industry or to a group of undertakings or industries. ${ }^{43}$

It is important to note that the White Paper expressly states that the purpose of Module 3 is to ensure that foreign subsidies can be addressed in individual public procurement procedures. ${ }^{44}$ It is the first indication that, unlike Module 1 and 2, Module 3 is focused more on the effects that foreign subsidy could produce to an individual procurement procedure, than on potential distortion of Internal Market. In the same sense, the White Paper further clarifies that it will be necessary to determine whether the foreign subsidy facilitates the participation in the public procurement procedure, enabling the economic operator benefitting from the subsidy to participate in the procedure, to the detriment of unsubsidized undertakings. In case of such distortive foreign subsidies, EU public buyers would be required to exclude from public procurement procedures those economic operators. ${ }^{45}$ In this regard, it is apparent from the White Paper that the main protective function of Module 3 is designed to benefit the tenderers who do not receive foreign subsidies.

As a first step envisaged within Module 3, economic operators participating in public procurement procedures should submit their notifications on subsidies to the contracting authority. It was expected that the White Paper would envisage an obligation for economic operators to include consortium members and subcontractors into notification, but to some extend it came as a surprise that the tenderer must also include information on its suppliers. ${ }^{46}$ The Commission contemplates on possibilities to set a threshold above which a notification will be mandatory, as well as to limit the relevant subsidy period to a period of three calendar years, in order to reduce the administrative burden and costs. ${ }^{47}$ A notification will have to at least the following elements: (i) legal information, including ownership and governance of the tenderer, any consortium member and those subcontractors and suppliers having received foreign financial contributions; (ii) main sources of overall financing of the tender; (iii) total amount of foreign financial contributions received in the past 3 years; (iv) foreign financial contributions received specifi-

\footnotetext{
White Paper p. 46

White Paper p. 46

White Paper p. 30

White Paper p. 30.

White Paper p. 31.

White Paper p. 31.
} 
cally for the purpose of participation in the public procurement procedure; (v) foreign financial contributions that will be received during the expected execution of the contract. ${ }^{48}$ In the Commission's opinion, Strict and deterrent tools should be put in place to deal with cases where economic operators fail to comply with the notification obligation, in which cases they could be sanctioned by the contracting authority with significant fines and in extreme situations excluded from the procurement procedure. ${ }^{49}$

Once the notification is filed with the contracting authority, next step is to be taken before the competent supervisory authority at Member State level. The role of the supervisory authority is to investigate information provided in the notification and to assess the existence of a foreign subsidy. The investigation of the supervisory authority is intended to have two phases, a preliminary review and an in-depth investigation, the latter to be entered only if the preliminary review ends with a conclusion that a foreign subsidy may exists. ${ }^{50}$ Final decision of the supervisory authority on existence of foreign subsidy is to be reached in close cooperation with the Commission, for which reason the supervisory authority shall inform the Commission on any draft decision. ${ }^{51}$

For the period of investigation, the contracting authority is obliged to refrain itself from awarding the contract to the investigated economic operator, but it is entitled to pursue the evaluation of the offers. If upon evaluation of offers the contract is to be awarded to the tenderer not to be the one under the foreign subsidy investigation, contracting authority is free to conclude the procurement procedure and to award the contract. Otherwise, if the evaluation of offers shows that the best offer is the one of the investigated tenderer, the procurement procedure will have to be suspended until the supervisory authority reaches its conclusions on the existence of foreign subsidies. ${ }^{52}$

If the supervisory authority comes to a conclusion that a tender under review is tainted with foreign subsidy granted to the tenderer, it shall refer the matter back to the contracting authority. In that case, a delicate task is conferred on the contracting authority: to determine whether that subsidy has distorted the public procurement procedure, and if so, to exclude the economic operator in question..$^{53}$ The exclusion may stay in force even for future procurements of the same con-

\footnotetext{
White Paper p. 31.

White Paper p. 32.

White Paper p. 32.

White Paper p. 33.

White Paper p. 33.

White Paper p. 34.
} 
tracting authority, preventing the excluded tenderer to participate in forthcoming procedures. The Commission envisages that such determination should be conducted on the basis of a uniform methodology, which could be set out in guidance, ${ }^{54}$ but provides no additional information on any criteria that should be used by the contracting authority when performing that task.

\subsection{Legal Analysis of Solutions Envisaged by the White Paper in the Context of Public Procurement Procedures}

Summary of the responses to the public consultation on the White Paper ${ }^{55}$ shows that a majority of EU Member States and EU stakeholders support the initiative to tackle foreign subsidies, in general and specifically regarding Module 3 and public procurement procedures. However, it should not be overlooked that some serious concerns were expressed, especially about the proposal on the sharing of responsibilities between contracting authorities and supervisory authorities. According to the Summary, Member States broadly agree that contracting authorities should not be responsible for assessing whether a foreign subsidy distorts the public procurement procedure, and that this task should instead be incumbent on the national supervisory authority or the Commission. ${ }^{56}$ It is hard not to share the same concern. Reasons in favor of this objection are well founded and correspond to everyday experiences in public procurement procedures. As first, contracting authorities lack the necessary expertise necessary to conduct such assessment, which could lead to numerous remedial procedures. Second, a risk of lack of impartiality could arise on side of contracting authorities, having short-term incentives to award tenders to subsidized bidders offering low prices. Third, a lack of efficiency may occur due to conducting of such assessments, resulting in prolonged procedures, and consequently negatively impacting the whole procurement. ${ }^{57} \mathrm{In}$ the same vein, it should be noted that the lack of information on the uniform methodology to be used by contracting authorities while determining whether a subsidy distorted the public procurement procedure, does not help clarifying the situation.

Further, if proposed concept of shared responsibilities between contracting authorities and supervisory authorities remains, it would mean that the supervisory

\footnotetext{
54 White Paper p. 34.

55 Summary of the responses to the public consultation on the White Paper on levelling the playing field as regards foreign subsidies (Summary), [https://ec.europa.eu/competition/international/overview/ WP_foreign_subsidies2020_summary_public_consultation.pdf], accessed 20 April 2021.

56 Ibid., p. 7.

57 Ibid.
} 
authority, a public body specialized in matters of subsidies, will stay limited solely to the question whether foreign subsidy exists. By contrast, contracting authority, not specialized in that particular field, shall be obliged to decide whether the subsidy distorted the public procurement procedure, in which case it shall exclude that economic operator for the procurement procedure. A decision on exclusion has a potential to produce far more significant repercussions than a decision on existence of a foreign subsidy and yet it is envisaged in the White Paper that, unlike the latter, it should be rendered by a non-specialized contracting authority. At the same time, even the Commission acknowledges that in practice contracting authorities do not have the information necessary to investigate whether bidders benefit from foreign subsidies or to assess to what extent the subsidies have the effect of causing distortions in procurement markets. ${ }^{58}$ It should be noted that the opposing views on this issue have also been expressed recently. In that vein, it is argued that the first responsibility to assess potential subsidies should remain in the hands of the contracting authorities - which are, according to that view, in the best position to interrogate vendors regarding alleged foreign subsidies. ${ }^{59}$ To some extent this line of argumentation can easily be accepted, but it is clear that it does not provide answers to the questions raised above on the lack of expertise and impartiality among contracting authorities.

To conclude on the role of supervisory authority, it should be noted that the entire Module 3 is based on a concept of self-notification, that must be conducted by each economic operator participating in the procurement procedure. With that regard, it seems that the role of supervisory authority will in most cases be exhausted in processing of information provided by the economic operators themself. In such cases it is not clear what would be the role of the supervisory authority other than to examine the authenticity and the veracity of the notification containing self-assessment made by economic operators. Most cases of economic operator declaring financial contributions received from foreign government will probably end only in supervising authority's confirmation that such financial contribution represents foreign subsidy as defined in the White Paper. The definition of foreign subsidy is broad enough to prevent occurrence of a lot of cases of economic operators notifying on financial contributions as potential foreign subsidies, for which the supervisory authority later determines that do not fall within the definition provided by the White Paper. It seems that the role of the supervisory authority

White Paper p. 11.

59 Biondi, A., Bowsher, M., Yukins, C., Rubini, L., Carovano, G., "The EU Gives Foreign Subsidies Its Best Shot": One Take on White Paper on Levelling the Playing Field as Regards Foreign Subsidies, [https:// ielp.worldtradelaw.net/2020/10/guest-post-the-eu-gives-foreign-subsidies-its-best-shot-one-take-onwhite-paper-on-levelling-the-pla.html], accessed 20 April 2021. 
will be highlighted only in cases of competitors' applications filed against an economic operator, arguing that it has received foreign subsidy and therefore should be excluded from the procurement procedure. If so, it can be concluded that the foreign subsidy argument will be mostly used as tool of other competitors trying to win the tender, which is actually in line with previously identified purpose of Module 3, designed to protect, in each individual case, the tenderers who do not receive foreign subsidies. Side effect of this approach could occur in significantly increased number of competitors' applications, due to the fact that all tenderers have strong incentives to eliminate other competitors, using any legal ground available. This side effect is already recognized by some authors as "Competitors' Strategic Manipulation" or "strategic whistleblowing". ${ }^{00}$

Among other remarks given to the White Paper, issues of administrative burden and possible delays in procurement procedures deserves particular attention. In that sense, some Member States expressed concerns that Module 3 risks being administratively heavy. ${ }^{61}$ It is argued by others that competitors' applications filed to supervisory authorities have a potential to delay procurement for months while procuring agencies and the Commission assess the competitors' claims of foreign subsidies - and that those delays could be extended in a second round of disruption, as the affected parties brought bid challenges. ${ }^{62}$ These risks are real and cannot be overstated. Everyday practice shows that contracting authorities of some Member States already deal with a considerable difficulty while conducting procurements of large-scale projects, especially in construction and infrastructure sectors. This is particularly evident when it comes to financial corrections and recoveries for the projects co-financed by EU funds. Such financial corrections are a consequence of irregularities made by contracting authorities during project implementation. Considering that most irregularities are not intentional but rather caused by lack of expertise on the side of contracting authority, it is clear that contracting authorities are already faced with a significant burden of regulatory requirements. In that sense, the obligation to assess and deal with foreign subsidies will for sure add to the complexity of their position.

Finally, a word should be said on the question posed in the title of this paper. It seems there are at least two reasons why it could be argued that Module 3 is not limited to the aim of levelling playing field, but also comprises of some protectionist features, or at least features not directly connected with the aim of levelling playing field. The first such glimpse can be found in the express acknowledgement

\footnotetext{
$60 \quad$ Ibid.

61 op. cit. note 55 , p. 7.

62 Biondi, A., Bowsher, M., Yukins, C., Rubini, L., Carovano, G., op. cit. note 59.
} 
made by the Commission that foreign subsidies are sometimes granted for achieving strategic goals of third countries, as to get privileged access to critical and major infrastructure. ${ }^{63}$ If this was one of incentives for designing modules presented in the White Paper, it is clear that the purpose of these modules is not only to ensure level playing field in the Internal Market, but to protect strategic interests of the EU and Member States. Given that the notion of strategic interest is subject to interpretation, this approach could open the way for additional measures in the future, with a clearer protectionist note. The second indication of protectionist approach regarding public procurement is even more pronounced. It has been shown above that the main function of Module 3 is to protect the tenderers who do not receive foreign subsidies against the subsidized competitors. Beneficiaries of such protection primarily are economic operators with a predominant intraEU ownership structure, colloquially termed as European companies. If there is a measure intended to protect domestic companies against foreign competitors, on any ground whatsoever, it could hardly be denied that such measure has a potential to be used for protectionist purposes. However, a mere potential for producing protectionist effects should not be understood as a certainty of its realization. This matter will largely depend on the practical application of Module 3 once the respective legislation enters into force. It can be expected that European companies will try to take advantage of this instrument, using it in a "strategic whistleblowing" sense, in order to eliminate non-EU competitors. It is up to legislators to set efficient legal barriers to such manipulative actions. At the same time, contracting authorities will need to invest a particular effort to identify and resist such actions.

\section{CONCLUSION}

COVID-19 pandemic brought to the forefront issues of foreign subsidies and of distortive impact such subsidies have in the Internal Market. The Commission addressed these issues by adopting the White Paper. It is a comprehensive document, aiming at levelling playing field in the Internal Market, in general and in some particular niches. With regard to foreign subsidies and the public procurement, the Commission analyzed in the White Paper the actual situation on the Internal Market and the adequacy of the existing legal framework, to detect if any significant regulatory gaps exist, enabling subsidized economic operators to take advantage over non-subsidized companies. As shown, the most obvious regulatory gap is manifested in the fact that the legislation in force does not envisage a ground for exclusion of the tenderer who received foreign subsidies, while at same time contracting authorities are obliged to exclude tenderers who received State aid

\footnotetext{
63 White Paper p. 8.
} 
incompatible with the Internal Market. Although there were attempts to overarch the regulatory gap by using the abnormally low tender provision, it was shown in the paper that this provision is not suitable for such role.

Upon a brief preview of the procedural steps envisaged by the White Paper within Module 3, the paper focused on analyzing the proposed measures, trying to establish key features of the approach designed by the Commission. It is noted that Module 3, designed for the area of public procurement, has an emphasized function of providing protection to non-subsidized companies, against the competitors who received foreign subsidies. In that sense, Module 3 differs to some extent from Modules 1 and 2, which are much more focused on the protection of the Internal Market taken as a whole, than on a protection of individual tenderers.

Although the White Paper has a strong support within the EU, certain concerns were expressed during the public consultation process, especially regarding the proposed idea of sharing responsibilities between contracting authorities and supervisory authorities, as well as in connection to additional administrative burden and possible delays in public procurement procedures, which may occur due to measures proposed to tackle foreign subsidies. Those concerns are not unfounded and should be taken into account while drafting the legislative proposal.

The paper ends showing that the reach of Module 3 is not limited just to ensuring level playing field, but it has potential to be used for protectionist purposes. Chances for protectionist effects to occur can be reduced by efficient legal barriers designed to prevent unfounded actions of other tenderers, interested in eliminating competition.

\section{REFERENCES}

\section{BOOKS AND ARTICLES}

1. Sanchez-Graells, A., Public Procurement and the EU Competition Rules, Hart Publishing, Oxford, 2015.

2. Semple, A., A practical guide to public procurement, Oxford University Press, Oxford, 2015.

3. Steinicke, M., Vesterdorf, P. L., EU public procurement law, Nomos Verlagsgesellschaft, Baden-Baden 2018.

\section{EU LAW}

1. Directive 2014/24/EU of the European Parliament and of the Council of 26 February 2014 on public procurement and repealing Directive 2004/18/EC (Directive 2014/24/EU), OJ L 94

2. Regulation 2016/1037 of the European Parliament and of the Council of 8 June 2016 on protection against subsidized imports from countries not members of the European Union, OJ L 176. 
3. Regulation 2019/712 of the European Parliament and of the Council of 17 April 2019 on safeguarding competition in air transport, and repealing Regulation (EC) No 868/2004, OJ L 123.

\section{DOCUMENTS}

1. Decision of Port Rijeka Authority No UP/I-342-01/20-01/26 of 30 December 2020., available at www.eojn.nn.hr

2. European Commission, White Paper on levelling the playing field as regards foreign subsidies of 17 June 2020, COM (2020) 253 final (White Paper)

3. European Commission, Guidance on the participation of third country bidders and goods in the EU procurement market of 24 July 2019, C (2019) 5494 final

\section{WEBSITE REFERENCES}

1. EU's next long-term budget\& Next Generation EU: key facts and figures, 2020, [https:// ec.europa.eu/info/sites/default/files/about_the_european_commission/eu_budget/mff_ factsheet_agreement_en_web_20.11.pdf], Accessed 20 April 2021.

2. Michaels, D., Pop, V., China faces European obstacles as some countries heed U.S. pressure, The Wall Street Journal online edition, [https://www.wsj.com/articles/china-faces-european-obstacles-as-some-countries-heed-u-s-pressure-11614088843] Accessed 20 April 2021.

3. Summary of the responses to the public consultation on the White Paper on levelling the playing field as regards foreign subsidies, [https://ec.europa.eu/competition/international/ overview/WP_foreign_subsidies2020_summary_public_consultation.pdf], accessed 20 April 2021

4. Biondi, A., Bowsher, M., Yukins, C., Rubini, L. \& Carovano, G. "The EU Gives Foreign Subsidies Its Best Shot": One Take on White Paper on Levelling the Playing Field as Regards Foreign Subsidies, [https://ielp.worldtradelaw.net/2020/10/guest-post-the-eu-gives-foreignsubsidies-its-best-shot-one-take-on-white-paper-on-levelling-the-pla.html], accessed 20 April 2021 